\section{Serhii Semeniuk, Vadym Povodzinskiy, Vladislav Shybetskiy}

\title{
THEORETICAL JUSTIFICATION OF SELECTING A METHOD FOR CULTIVATION OF MAMMAL CELLS AS A BASIS FOR DESIGNING MEMBRANE BIOREACTORS IN ACCORDANCE WITH THE REOUIREMENTS OF GOOD MANUFACTURING PRACTICE
}

The object of research is technological cultivation systems, the central element of which are bioreactors, which ensure efficient metabolism of mammalian cells (Metazoa). Fundamental differences in the phenotypic characteristics of mammalian cells from microorganisms and the special phase-hydrodynamic state of the cultivation system form special requirements for the design and operation of bioreactors. One of the most problematic areas in the process of using cell cultures to obtain medicinal products of biological origin is to ensure the correct cultivation conditions in order to obtain the maximum amount of the target product. The quality assurance system for drug production is based on good manufacturing practice, which puts forward a number of general requirements for the organization of production of drugs of specified quality, efficacy and safety.

The study analyzed the phenotypic characteristics of mammalian cells. The analysis of industrial cultivation systems is carried out and a new classification is proposed, which takes into account the phase-hydrodynamic state of the culture and the specifics of the hydrodynamics of the bioreactor. The analysis made it possible to determine membrane cultivation systems as the most promising. The choice of this cultivation system has a number of features, in particular, the provision of favorable conditions during a long process of cultivation of supportdependent cells. This system guarantees a constant and efficient supply of nutrients, including dissolved oxygen, and the removal of waste products. A wide range of materials for the manufacture of membranes allows to use an individual approach to different types of cell lines. Due to this, it is ensured that high cultivation rates are obtained - the density of cells on the growth surface, the provision of the necessary substances during the entire cultivation process without negative mechanical effects on the cells. The modular design of the membrane elements allows for scalability of the cultivation process from laboratory development to industrial cultivation. The results obtained in this work can be the initial data in the study of hydrodynamic and mass transfer characteristics and in the development or construction of new bioreactors, which will reduce the stage of laboratory development and accelerate the introduction of innovative drugs.

Keywords: technological culture systems, bioreactor design, mammalian cells, active pharmaceutical ingredient, biological agent, good manufacturing practice.

\section{How to cite}

Semeniuk, S., Povodzinskiy, V., Shybetskiy, V. (2021). Theoretical justification of selecting a method for cultivation of mammal cells as a basis for designing membrane bioreactors in accordance with the requirements of good manufacturing practice. Technology Audit and Production Reserves, 2 (3 (58)), 14-19. doi: http://doi.org/10.15587/2706-5448.2021.229666

\section{Introduction}

Among medicinal products, the prominent place is occupied by biological medicinal products, which are considered to be those in which the active substance/active ingredient (API) is a biological substance. This substance is a substance produced by a biological source or extracted from it [1].

Biological drugs include immunological drugs (vaccines, toxins, serums, or allergen drugs) and drugs obtained by biotechnological methods. In accordance with the requirements of good manufacturing practice (GMP), the production of biological APIs for humans can be realized using cell culture and fermentation. There are significant differences in the critical parameters of the production process for the production of biological APIs and APIs obtained by chemical synthesis [1, 2]. In contrast to APIs obtained by chemical synthesis, the quantity and quality of APIs of biological origin depends on a number of envi- 
ronmental factors, among which the most significant are the factors arising from cultivation:

- physical (intensity of hydrodynamic processes, processes of mass and heat transfer);

- chemical (changes in the composition of the nutrient medium - sorption/metabolism of nutrients and the formation of metabolites, which leads to changes in the concentration of interacting phases, etc.);

- biological (it is possible to change the phenotypic characteristics of biological agents (BA), the possibility of contamination, a change in the API confirmation structure, etc.)

Based on the peculiarities of the phenotype of the cell population and the specificity of the hydrodynamics of the bioreactor, the correct analysis of the specificity of the cultivation of mammalian cell cultures (MC) in vitro in known industrial and semi-industrial systems.

For industrial implementation, the formation of initial data and technical specifications for the design and study of industrial types of bioreactors remains relevant. The proposed concept is based on the need to obtain the maximum amount of API or cell mass within the genetically determined properties of cell cultures by regulating environmental factors [3]. The fulfillment of the task should meet the requirements of the GMP and be based on the analysis of information on the $\mathrm{AD}$ phenotype of cell cultures. The main conditions for fulfilling the GMP requirements at the stage of working with seed and working cell banks is to ensure the standard and safety of MC [2].

Thus, the object of research is technological cultivation systems, the central element of which is bioreactors that ensure the efficient metabolism of mammalian cells (Metazoa). And the aim of research is to develop a modern classification of systems for the MC cultivation, based on the characteristics of the phenotype of the population, the phase-hydrodynamic state of the system and the mobility of the environment.

\section{Methods of research}

2.1. Morphological indicators. To calculate the intensity of mass exchange processes, the initial information is the MC morphology, namely, the determination of the MC specific surface area, and for this it is necessary to know the size of individual cells. For example, the minimum size of spherical blood cells is $4-6$ microns [4]. The cell shape is variable and depends on the culture conditions.

2.2. Cytoplasmic membrane. Contact with the $\mathrm{MC}$ environment is carried out through the cytoplasmic membrane $(\mathrm{CPM})-7-12 \mathrm{~nm}$ thick. CPM is a product of cytoplasmic differentiation. Microvilli and wrinkles may be present on the CPM surface, which, by increasing the specific surface area, contribute to the intensification of mass transfer.

For the design of bioreactors, information is required on the processes of transport of nutrients into the cell. The intensity of mass transfer of components of the nutrient medium (NM) depends on the properties of the diffusion layers of the surface structures of the cell, which cause resistance in the processes of mass transfer.

In general, the CPM performs several functions a barrier, provides selective transport of nutrient medium components, a protective and receptor function. By its structure, the CPM is a three-layer structure containing two layers of fats (lipids) and protein molecules.

The main difference between MC and plant cells and microorganisms is the absence of a cell wall in the cell wall and, accordingly, the absence of some functions of resistance. The cell wall in plants and microorganisms performs a significant number of functions, among which the most specific is to ensure the resistance of cells to the effects of physical (hydrodynamic) environmental factors.

2.3. Cultural indicators. An essential factor in the modeling of bioreactors for the MC cultivation is the analysis of the population in a liquid nutrient medium. In this context, it is important to determine the type of contact of the surface of the phases and, therefore, the cell surface will be different for attached surface/substrate-dependent cultures and for suspension populations. Cultural features include the specificity of the growth of the MC population when using various methods of cultivation.

2.4. Adhesive surface/substrate dependent populations. Most MSs are surface/substrate adherent populations or monolayer culture (MLC), while others can be grown free floating in culture media (suspension culture). Some types of CS in suspension form cell agglomerates of various numbers and configurations. The suspension population is a supplement to adhesive cultures, it is an intermediate form of the MC existence.

Since most cell cultures are surface/substrate-dependent cultures, it is dealing with MLC. This type of crops, as a rule, includes primary crops (PC). In this case, the PC is those cells that have not been transplanted - not subcultured. After subculturing/reseeding, it becomes possible to switch from PC to a cell line and then obtain a permanent cell line. MLC systems are characterized by some specific cultural characteristics that significantly affect the modeling of processes in a bioreactor and their design:

- the majority of primary (non-transformed cells) grow after attachment to the surface - glass, plastic, metal after their appropriate processing;

- during the growth and formation of a single-layer surface, the influence of contact inhibition is monitored, manifested in the spreading of cells and a change in their specific surface area.

\section{Research results and discussion}

3.1. Suspension populations. Historically, the development of bioreactor designs is, as a rule, focused on the cultivation of microorganisms, and therefore the direction of MC cultivation in suspension arose. In this case, liquidphase culture systems can be classified according to the principle of energy input for homogenization (Fig. 1).

This classification system (Fig. 1) does not correspond to the MC cultivation specificity, since it does not take into account the fundamental differences between PC and permanent cell lines.

The proposed scheme (Fig. 2) is based on the phase state of culture, and the definition itself is immobile or movable cells. Moreover, the environment that ensures the efficiency of cultivation is also either movable or not.

Industrial and semi-industrial proposals were selected as objects of comparison assessment, which are known in the production of medicines and pharmacology. 


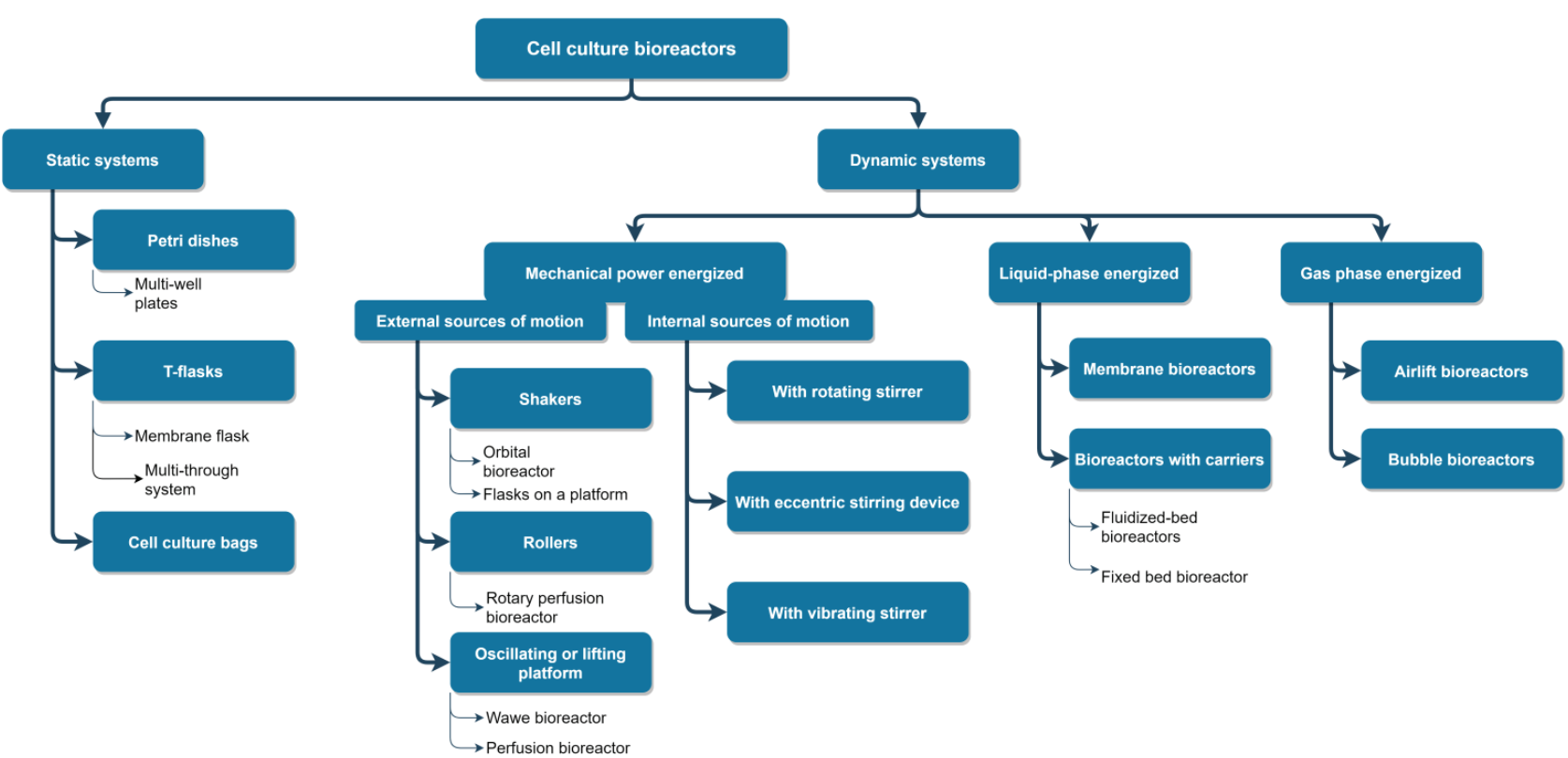

Fig. 1. Classification of bioreactors by the method of energy input [5]

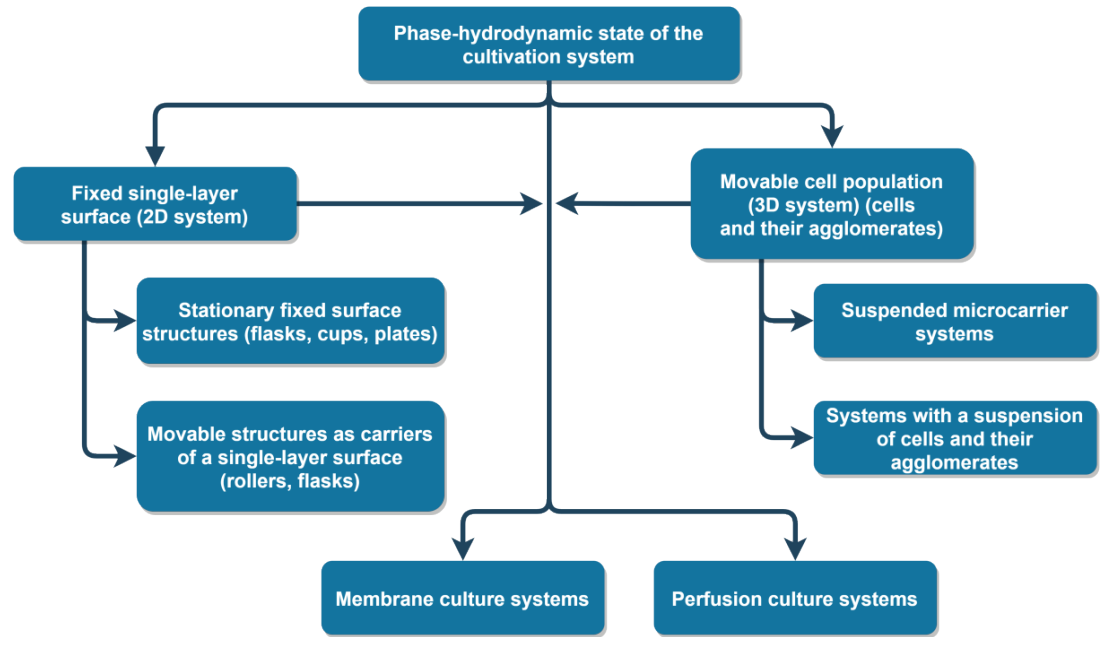

Fig. 2. Classification of systems for the cultivation of mammalian cultures according to the phase-hydrodynamic state of cells and the mobility of the environment
3.2. Fixed surface single layer surface in 2D System. Stationaryfixed surface structures (flasks, cups, plates). A fixed surface monolayer surface in a $2 \mathrm{D}$ system is the basis for research in the field of cell biology, pharmacology, etc. MC cultivation in a monolayer is the most correct technological solution for cultivation when working with primary cultures, cell banks, obtaining cell lines, etc.

The hardware design has remained largely unchanged since 1885, when Wilhelm Roux used a glass plate to MC culture. Cultivation of two-dimensional (2D) cell culture is carried out in Collet dishes, Petri dishes, stationary Roux flasks with a surface of up to $200 \mathrm{~cm}^{2}$, culture plates, etc. (Fig. 3). An essential feature of these cultivation systems is the guarantee of reproducibility of results.
The proposed modern classification scheme for the MC cultivation systems allows to analyze the known technological systems and determine possible promising technological solutions and technical design of the cultivation stage in accordance with the GMP requirements.

The scheme is based on the determination of the phenotypic characteristics of the MC and the analysis of the influence of the hydrodynamic parameters of the culture liquid (CL) on the cultivation efficiency. This classification allows to offer correct technological solutions for the formation of project documentation in accordance with the GMP requirements to ensure the standard and MC safety. In this case, the fulfillment of the GMP requirements is focused on ensuring and obtaining reproducible results of cultivation, which is possible if the control and regulation of technological indicators is observed.

Usually, the practical obtaining of reproducible results is possible by ensuring control over the hydrodynamic and mass transfer characteristics of the bioreactor operation and their operational regulation.

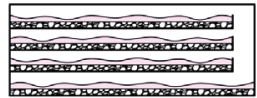

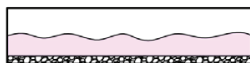

Nutrient medium

$a$
(1)

- Cell culture

b
Fig. 3. Schematic representation of a stationary surface cultivation system: $a$ - cultivation in a Petri dish; $b$ - cultivation in a Roux flasks

Movable structures, as carriers of a single-layer surface (rollers, flasks). For systems with a fixed single-layer 2D cell culture, roller systems are the most famous and advertised. From the point of view of hydrodynamics and mass transfer, they allow the transition from the mechanism of molecular diffusion to a technologically controlled process of convective diffusion [6]. Controlled characteristics - technological parameters are the roller rotation speed and the filling factor of the roller with the nutrient medium [7]. 
For roller systems (Fig. 4), the question of regulating the intensity of transport of one of the limiting the efficiency of substrate biosynthesis, which is molecular oxygen, remains open. When using roller systems, the amount of the gas phase is limited by the volume, it is not filled with NM and in this system this leads to the accumulation of gaseous metabolic products.

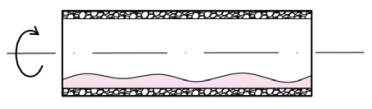

\section{- Nutrient medium - Cell culture}

Fig. 4. Schematic representation of a movable single-layer system cultivation in a roller

3.3. Movable cell population (3D system) of the cells and their agglomerates. Suspended microcarrier systems. For leveling the significant disadvantages of traditional bioreactors in the MC biotechnology, such as damaging mechanical factors, the influence of the bubble phase, cultivation systems with the use of microcarriers were created (Fig. 5). In known systems, protein or polysaccharide frameworks in the form of particles with a size of 50-400 microns are used as matrix carriers, on the surface of which a monolayer of cells is formed [8].

Cultivation on microcarriers allows to use the positive features of monolayer and suspension cultivation.

Systems with a suspension of cells and their agglomerates. The use of microcarrier systems is limited by the high cost of microcarriers. Therefore, the advantages of suspension cultivation can hardly be overestimated, since under such conditions it is possible to cultivate MC with the maximum yield of the target metabolite or cell mass, subject to the requirements of GMP to ensure standardization and safety. The creation of a suspension cultivation system is based on the practice of using standard bioreactors that have been used for a long time in biotechnology.

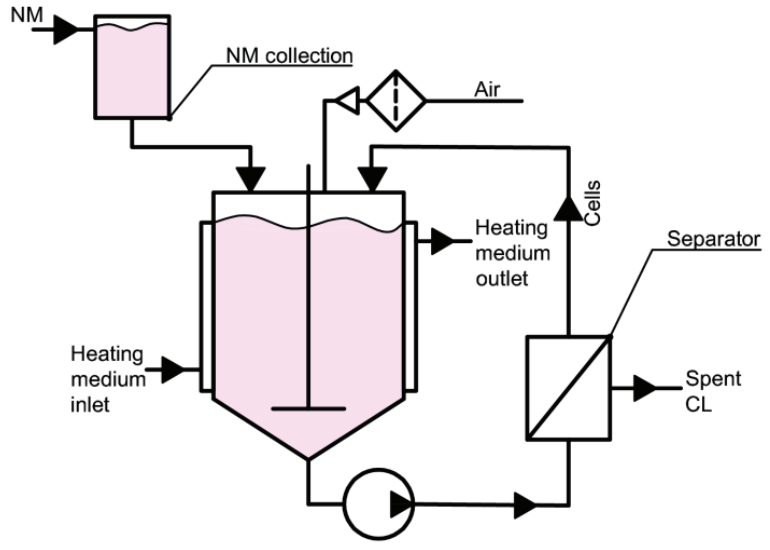

Nutrient medium
Suspension cultivation of isolated cells and cell agglomerates of small numbers is used in the cultivation of primary cells and some transformed (Hela, VIK-21 SNO, etc.) [9]. It should be noted that the so-called wave bioreactors have found their place among suspension cultivation systems. Among the systems with wave bioreactors, the most famous are single use systems.

Perfusion systems. In this context, perfusion is a continuous cultivation method, in which CR fractionation is used, and the separated cells are returned to the bioreactor, which contains a new nutrient medium (Fig. 6). This technological method allows to remove the limitation of metabolism by the deficiency of the substrate and metabolic products. The cell mass can be presented as adhesion cultures in the state of a fixed single-layer surface, and as a suspension.

Hollow fiber bioreactors. Noteworthy are bioreactors with modules, which are packages/cartridges with microfiltration hollow elements with an inner diameter of no more than $5 \mu \mathrm{m}$, the internal cavities of which form cultivation chambers with a fixed cell layer [10]. Hollow fiber systems allow achieving high titers $-\left(10^{7}-10^{8}\right.$ cells per milliliter) due to the high specific surface area of hollow cartridges.

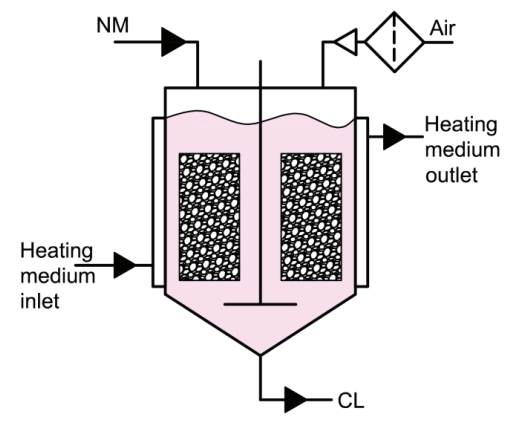

Nutrient medium

a

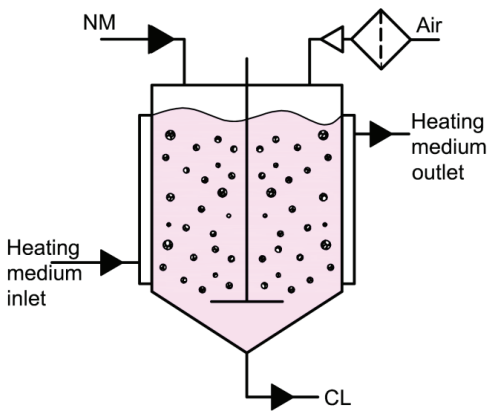

- Cell culture

$b$

Fig. 5. Schematic representation of the microcarrier culture system: $a$ - a system with a fixed layer of microcarriers; $b$ - a system with microcarriers in the suspension form

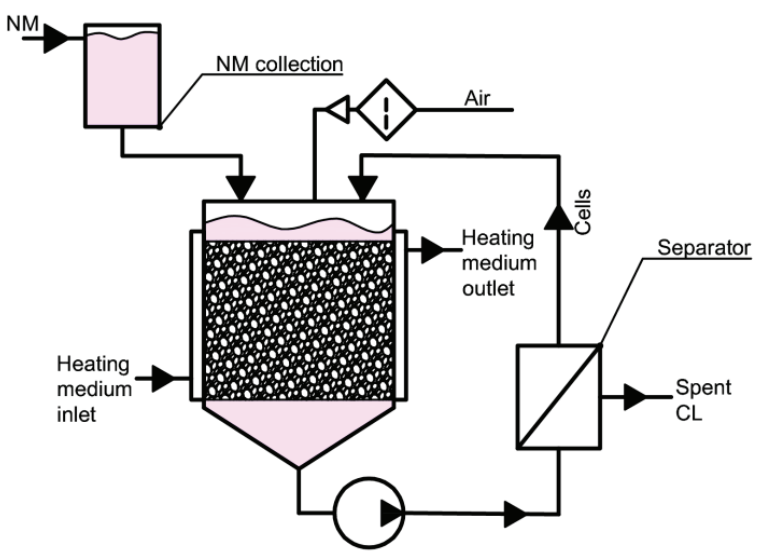

Cell culture

$b$

Fig. 6. Schematic representation of the perfusion culture system: $a$ - with cells in suspension; $b$ - with cells fixed on carriers 
Typically, hollow fiber bioreactors (HFBs) are divided into 2 main categories depending on the configuration of the cartridge:

- cylindrical hollow fiber bioreactors cHFB;

- rectangular hollow fibers rHFB (rectangular hollow fiber bioreactors).

A typical installation consists directly of:

- a cartridge with a hollow fiber module, where the cultivation of cell cultures takes place;

- module for saturation of the nutrient medium with technological gases $\left(\mathrm{O}_{2}, \mathrm{CO}_{2}\right)$;

- containers with a nutrient medium;

- sensors for monitoring technological parameters;

- a pump for pumping the culture medium or additional components into the culture medium [11].

Hollow fibers can be made from cellulosic, polysulfone, polypropylene or polyethylene materials, which allows for selection depending on the characteristics required for optimal production of the target product or the needs of the process. Cellulose fibers are widely used for uniform development of cells on their surface and for obtaining products resulting from the development of cell cultures.

The use of membranes as a surface for immobilization of cells allows solving a number of highly specific problems, which will be discussed below.

Membrane systems. Membrane systems for MC cultivation is the most modern technological and constructive solution, where it is supposed to transport nutrients to the cell mass and remove metabolites through a semipermeable membrane (Fig. 7).

The previously considered hollow fiber systems have the potential for improvement and they are used as a gauze/adhesive surface of membranes (tubular membranes) to create a culture space due to the selective transport of substrates across the membrane surface.

An example is the ACUSYST ${ }^{\circledR} \mathrm{X}$ Cell Generation bioreactor (USA). The use of membranes is a step towards the creation of culture systems in which the cells are protected by a membrane from mechanical damage and from the negative effect of the bubbly gas phase on the cells.
Biovest International (USA) developed the first commercial membrane bioreactor system in the mid-1980s, and since then the most widespread application of this technology has been the large-scale production of monoclonal antibodies and vaccines [12].

An interesting technological solution is known, where the perfusion culturing of cells was carried out in disposable wave-type bioreactors Sartorius Flexsafe RM 10L perfusion pro 1.2 my (Sartorius, Germany) with a built-in membrane. The working volume of the suspension was 3.0 liters. The seeding cell concentration is $0.5 \pm 0.1 \mathrm{mil}-$ lion/ml [13].

Another aspect of the use of membranes in bioreactors for the cultivation of cell cultures is the saturation of the culture liquid with dissolved oxygen (Fig. 7, b), avoiding the formation of a gas phase (air bubbles) inside the bioreactor. Membrane elements for oxygenation can be in the form of an external module, which allows saturation of the nutrient medium with dissolved oxygen, without the formation of foam, damage to cells due to their contact with the contact surface of the «liquidgas» phases.

Also, the membranes can be integrated into the internal volume of the bioreactor.

An innovative direction is DMA (Dynamic Membrane Aeration), the essence of which is that the aeration device in the form of polymer membranes acts as a stirring device.

Known designs of bioreactors with dynamic aeration technology from Bayer Health Care (Germany) with a volume of 12-200 liters and are used for the production of Kogenate $^{\circledR}$ and Zevalin ${ }^{\circledR}$ [14].

3.4. Discussion of research results. The existing systems for the cultivation of cell cultures were considered and their classification according to the phase-hydrodynamic state was proposed.

Based on the analysis of the features of known cultivation systems, a membrane cultivation system was chosen, since it is the most suitable for the requirements of the GMP (controllability and reproducibility of the process).

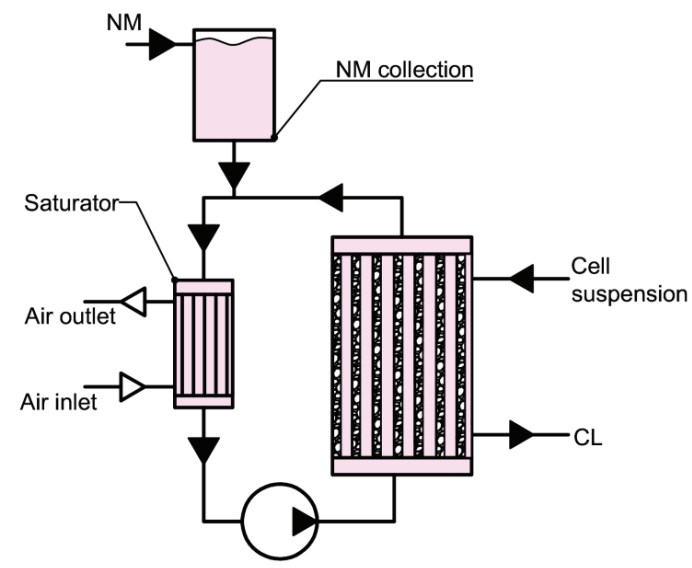

- Nutrient medium

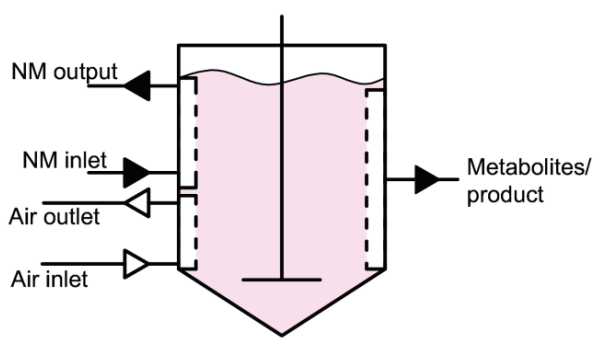

- Cell culture

$a$

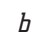

Fig. 7. Schematic representation of the membrane culture system:

$a$ - a system with immobilized cells; $b$ - a system with suspended cells and agglomerates 
Membrane bioreactors for culturing MC cells have a number of advantages, among which the following should be noted:

- favorable conditions for the cultivation of cell cultures due to the minimization of the action of shear forces and the absence of contact of air bubbles with the cell surface (no bulbless aeration);

- high productivity in terms of cell mass (for example, in a hollow membrane bioreactor, it is possible to create a cell density of up to $10^{12}$ cells $/ \mathrm{ml}$, in contrast to the classic suspension bioreactor up to $10^{6}$ cells $/ \mathrm{ml}$ );

- possibility of constant removal of metabolic products, which can negatively affect the growth of cells, and

a constant supply of nutrient components;

- developed surface of cell adhesion;

- modular design allows to change the volume of production without additional costs for scaling the process; - single-use membrane modules (singe-use systems), do not require the cost of cleaning and sterilization processes.

The disadvantages include problems with the separation of cells from the membrane surface after the end of the cultivation process and restrictions on scaling to large industrial batches.

\section{Conclusions}

The study analyzed the critical parameters of mammalian cell culture in existing industrial culture systems. A new classification of cultivation systems has been developed, taking into account the phase-hydrodynamic state of cells and the mobility of the medium. The analysis made it possible to determine the prospects of using membrane cultivation systems.

The research results can be used as a basis for the formation of initial data in the design or study of the hydrodynamic and mass transfer characteristics of new cultivation systems. Identifying and adjusting the key parameters of the cultivation process at the laboratory development stage is critical not only to reduce the time and budget for drug development, but also to improve the efficiency of the process.

\section{References}

1. ST-N MOZU 42-3.4:2020. Likarski zasoby nastanova z vyrobnytstva hotovykh likarskykh zasobiv (2020). Kyiv: Ministerstvo okhorony zdorovia Ukrainy. Available at: https://compendium.com.ua/ $\mathrm{uk} /$ clinical-guidelines-uk/standartizatsiya-farmatsevtichnoyiproduktsiyi-tom-3/st-n-mozu-42-3-4-2020/

2. Petrelli, F., Caraffa, A., Scuri, S., Grappasonni, I., Magrini, E., Cocchini, A. (2019). The requirements for manufacturing highly active or sensitising drugs comparing Good Manufacturing Practices. Acta bio-medica, 90 (2), 288-299. doi: http://doi.org/ 10.23750/abm.v90i2.8340
3. Salehi-Nik, N., Amoabediny, G., Pouran, B., Tabesh, H., Shokrgozar, M. A., Haghighipour, N. et. al. (2013). Engineering Parameters in Bioreactor's Design: A Critical Aspect in Tissue Engineering. BioMed Research International, 2013, 1-15. doi: http:// doi.org/10.1155/2013/762132

4. Petrov, I., Neguliaev, I. (2011). Srednii razmer kletki kak faktor, otrazhaiuschii vzaimodeistvie kletok linii SNO v protsesse ikh proliferatsii. Tsitologiia, 53 (8), 671-678.

5. Eibl, R., Eibl, D., Pörtner, R., Catapano, G., Czermak, P. (2009) Cell and tissue reaction engineering. Springer, 363. doi: http:// doi.org/10.1007/978-3-540-68182-3

6. Ruzhynska, L. I., Shybetskyi, V. Yu., Povodzynskyi, V. M. (2010). Modeliuvannia hidrodynamiky rollernoho fermentera u biotekhnolohii vaktsyn. Naukovyi visnyk Lvivskoho natsionalnoho universytetu veterynarnoi medytsyny ta biotekhnolohii imeni S. Z. Gzhytskoho, 12 (2-4 (44)), 76-81.

7. Shybetskiy, V., Semeniuk, S., Kostyk, S. (2017). Design of consrtuction and hydrodynamic modeling in a roller bioreactor with surface cultivation of cell cultures. ScienceRise, 7 (36), 53-59. doi: http://doi.org/10.15587/2313-8416.2017.107176

8. Radaeva, I., Dumchenko, N., Nechaeva, E. (2019). The cultivation of cells on microcarriers in bioreactors. PNRPU Bulletin. Chemical Technology and Biotechnology, 2, 22-32. doi: http:// doi.org/10.15593/2224-9400/2019.2.02

9. Julaey, M., Hosseini, M., Amani, H. (2016). Stem Cells Culture Bioreactor Fluid Flow, Shear Stress and Microcarriers Dispersion Analysis Using Computational Fluid Dynamics. Journal of Applied Biotechnology Reports, 3 (2), 425-431.

10. Pinxteren, J. A. M., Craeye, D. (2012). Pat. US 2012/0308531 A1. Expansion of Stem Cells in Hollow Fiber Bioreactors. MPK: C12M23/16. Published: 06.12.2012.

11. Yan, I. K., Shukla, N., Borrelli, D. A., Patel, T. (2018). Use of a Hollow Fiber Bioreactor to Collect Extracellular Vesicles from Cells in Culture. Methods in Molecular Biology. Extracellular RNA, 35-41. doi: http://doi.org/10.1007/978-1-4939-7652-2 4

12. Dhainaut, F., Meterreau, J. L., Mas, M. P., Potentini, C., Mignot, G. (1992). Scale-up of human IgG1 production by a lymphoblastoid cell line in hollow fiber systems. Animal Cell Technology, 527-259. doi: http://doi.org/10.1016/b978-0-7506-0421-5.50118-5

13. Vachette, E., Fenge, C., Cappia, J. M., Delaunay, L., Greller, G., Barbaroux, M. (2014). Robust and convenient single-use processing: The superior strength and flexibility of flexsafe bags. BioProcess International, 12.

14. Frahm, B., Brod, H. (2011). Improving Cell Culture Bioreactor Performance for Sensitive Cell Lines by Dynamic Membrane Aeration (DMA). Proceedings of the 21st Annual Meeting of the European Society for Animal Cell Technology (ESACT). Dublin, 355-358. doi: http://doi.org/10.1007/978-94-007-0884-6_56

Serhii Semeniuk, Postgraduate Student, Department of Biotechnics and Engineering, National Technical University of Ukraine «Igor Sikorsky Kyiv Polytechnic Institute», Kyiv, Ukraine; Pharmaceutical Corporation Artertium, Kyiv, Ukraine, ORCID: https://orcid. org/0000-0003-4136-8365, e-mail: sem2mn@gmail.com

Vadym Povodzinskiy, PhD, Associate Professor, Department of Biotechnics and Engineering, National Technical University of Ukraine «Igor Sikorsky Kyiv Polytechnic Institute», Kyiv, Ukraine, ORCID: https:// orcid.org/0000-0002-9591-909X, e-mail:vnpovodzinski@ukr.net

Vladislav Shybetskiy, PhD, Associate Professor, Department of Biotechnics and Engineering, National Technical University of Ukraine «Igor Sikorsky Kyiv Polytechnic Institute», Kyiv, Ukraine, ORCID: https:// orcid.org/0000-0001-5482-0838, e-mail: v.shybetsky@gmail.com 